Mini review

\title{
Research Progress and Application Prospects of Electrochemical Glucose Sensors
}

\author{
Lingbin $\mathrm{Ou}^{1, *}$, Gang $\mathrm{Liu}^{2}$ and Ning $\mathrm{Xia}^{2, *}$ \\ ${ }^{1}$ School of Medical Technology, Yongzhou Vocational Technical Colledge, Yongzhou 425100, \\ Hunan, China \\ ${ }^{2}$ Henan Province of Key Laboratory of New Optoelectronic Functional Materials, Anyang Normal \\ University, Anyang 455000, Henan, China \\ *E-mail: xiaobinxuer@163.com (L.O.); xianing82414@163.com (N.X.)
}

doi: $10.20964 / 2021.06 .42$

Received: 13 March 2021 / Accepted: 5 April 2021 / Published: 30 April 2021

The detection of glucose plays an important role in the diagnosis, treatment and control of human diseases. The enzyme-based electrochemical sensors for glucose detection have the advantages of high sensitivity, good selectivity and mild conditions. However, the enzyme activity is easily interfered by external conditions, which limits the application of enzyme-based sensors. By contrary, enzyme-free sensors can overcome these shortcomings and achieve continuous glucose monitoring. Recently, various materials have been developed and applied for electrochemical detection of glucose. This review summarized the recent progress and application prospects of enzyme-based and enzyme-free electrochemical glucose sensors.

Keywords: Electrochemical glucose sensor; glucose oxidase; enzyme-free; nanomaterials; wearable sensor

\section{FULL TEXT}

(C) 2021 The Authors. Published by ESG (www.electrochemsci.org). This article is an open access article distributed under the terms and conditions of the Creative Commons Attribution license (http://creativecommons.org/licenses/by/4.0/). 